\title{
Three species of sedges (Cyperaceae) new to Bihar, India
}

\author{
Anant Kumar, Gopal Krishna四 and V. P. Prasad \\ Central National Herbarium, Botanical Survey of India, Howrah - 711103, India \\ 凶Corresponding author:gopal_bsi@yahoo.co.in
}

\section{बिहार राज्य के लिए सेड्ज (सायपरेसी) के तीन नये अभिलेख}

\author{
अनन्त कुमार, गोपाल कृष्ण एवं वी. पी. प्रसाद
}

\section{सारांश}

बिहार राज्य के औंरगाबाद और नवादा जिलों से सेड्ज कुल सायपरेसी की तीन जातियां फिमब्रिस्टाइलिस एल्बोविरिडिस सी.बी. क्लाक, कायल्लिंगा बुलबोसा पी. बियूव व लिपोकार्फा स्कुवारोसा (लिनि.) गोटेग अन्वेषित की गई हैं। प्रस्तुत शोध पत्र में इन जातियों की आसानी से पहचान के लिए ऋतुजैविकी का संक्षिप्त विवरण और एक फोटोप्लेट दी गई है।

\section{ABSTRACT}

Three species of Cyperaceae, Fimbristylis alboviridis C.B. Clarke, Kyllinga bulbosa P. Beauv. and Lipocarpha squarrosa (L.) Goetgh., are reported for the first time from Bihar, India based on the collections from Aurangabad and Nawada districts. The present paper provides a brief description, phenology and a photoplate of these species for easy identification.

Keywords: Fimbristylis, Kyllinga, Lipocarpha, Bihar, Cyperaceae, New record

\section{INTRODUCTION}

The family Cyperaceae is represented by 140 species under 35 genera in Bihar (Singh \& al., 2001). During 2013-2015, about 26 taxa of different species of sedges were collected from Aurangabad and Nawada Districts of Bihar. On thorough examination of the specimens and a perusal of relevant literature (Clarke, 1893-1894, 1909; Haines, 1924; Mooney, 1950; Singh \& al., 2001 and Sharma \&
Sarkar, 2002) revealed that three species viz., Fimbristylis alboviridis C.B. Clarke, Kyllinga bulbosa P. Beauv. and Lipocarpha squarrosa (L.) Goetgh, have not been reported from state of Bihar. Hence, these are reported here as new additions to the flora of Bihar. A brief description of each species along with their nomenclature citations, phenology, a reference to the available illustration and distribution are provided. A photo plate of these species is also included for their easy identification (Plate 1). 


\section{TAXONOMY}

1. Fimbristylis alboviridis C.B. Clarke in Hook. f., Fl. Brit. India 6: 638. 1893; Karthik. \& al., Fl. Ind. Enum. Monocot. 50. 1989.

Plate 1. a, a1

Annuals with fibrous roots. Culms tufted, compressed, trigonous, $15-25 \mathrm{~cm}$ long, $0.5-1 \mathrm{~mm}$ thick, glabrous. Leaves half as long as the culm, often slightly falcate, 1-2 $\mathrm{mm}$ wide, obtuse to rather acute at apex, scabrid along margins in upper part, greyish-green; ligule a fringe of short, white hairs. Inflorescence simple or subcompound, loose, 2-7 cm long, with few to several spikelets. Involucral bracts 1-2, lowest somewhat shorter than to twice as long as the inflorescence. Primary rays few, up to $5 \mathrm{~cm}$ long, smooth. Spikelets solitary, terete, ovoid to oblongovoid, 3-5 $\times$ c. $2 \mathrm{~mm}$, acute at apex, densely many-flowered, whitish or greyish-green, often brownish-variegated; rachilla narrowly winged. Glumes spiral, subchartaceous, broadly ovate, $c .2 \times 2 \mathrm{~mm}$, obtuse at apex, muticous or scarcely apiculate, with 3-nerved keel and nerveless sides, glabrous, brownish, hyaline towards base and margins. Stamen 1; anther oblong. Ovary obovoid; style slightly dilated at base, c. $1 \mathrm{~mm}$ long, ciliate above; stigmas 2, shorter than style. Achene biconvex, obovate, 1-1.2 $\times$ 0.7-0.9 mm, shortly stipitate, umbonulate at apex, scalyverruculose, obtusely reticulate, stramineous; epidermal cells transversely elliptic or oblong, in 10-16 vertical rows on each face.

Flowering and Fruiting: September - October.

Illustration: J. Kern in Steenis, Fl. Malesiana 1, 7: 580, f. 46.1974.

Distribution: Commonly found along ponds and roadsides; Western Peninsular India, Central, Eastern, and North-Eastern India, and Andaman \& Nicobar Islands.

Specimens examined: Bihar: Nawada district, Rajauli, 17.09.2013, Gopal Krishna \& Anant Kumar 65702 (CAL); Nawada district, 17.09.2013, Gopal Krishna \& Anant Kumar 66971 (CAL).

2. Kyllinga bulbosa P. Beauv., Fl. Oware 1: 11. 1805. K. triceps Rottb., Descr. Ic. 14, t. 4, f. 6. 1773, nom. illeg: C.B. Clarke in Hook. f., Fl. Brit. India 6: 587. 1893. K. tenuifolia Steud., Syn. Pl. Glum. 2: 69. 1855; Karthik. \& al., Fl. Ind. Enum. Monocot. 61. 1989. Cyperus richardii Steud., Syn. Pl. Glumac. 2: 8. 1854.

Plate 1. b, b1

Perennials with short rhizome, $15-25 \mathrm{~cm}$ high; stolons absent. Culms tufted, trigonous, $0.5-1.5 \mathrm{~mm}$ thick, with an ovoid enlargement at base covered by brownish fibers of disintegrating sheaths. Leaves shorter or longer than the culm, 1-3 mm wide, gradually acuminate at apex; sheaths often brownish at base. Inflorescence a head of (1-)3(-5) sessile spikes; central spike globose to ovoid-globose, 5-9 $\times 5-6 \mathrm{~mm}$, obtuse at apex; lateral ones globose, smaller. Involucral bracts $3-4$, up to $10 \mathrm{~cm}$ long. Spikelets numerous, densely packed, strongly compressed, oblong to oblong-lanceolate, $1.5-2 \times 0.5-1 \mathrm{~mm}$, acute at apex, pale green to whitish, 1-flowered; rachilla short, disarticulating at base. Glumes mostly 4, ovateoblong to oblong-lanceolate, acute to submucronulate at apex, with a smooth keel. Stamens 2; filaments elongate up to $2.5 \mathrm{~mm}$; anthers linear-oblong. Ovary oblong; style c. $0.5 \mathrm{~mm}$ long; stigmas 2 , up to $0.8 \mathrm{~mm}$ long. Achene laterally compressed, oblong, $1.2-1.5 \times 0.5-0.7 \mathrm{~mm}$, apiculate at apex, brownish.

Flowering and Fruiting: May - October.

Illustration: Matthew, Illus. Fl. Tamilnadu Carnatic Pl. 785. 1982.

Distribution: Found in moist sandy soils in hilly areas; throughout India.

Specimens examined: Bihar: Nawada district, Near Kakolat fall, 15.09.2014, Gopal Krishna \& Anant Kumar 66999 (CAL)

3. Lipocarpha squarrosa (L.) Goetgh. in Wageningen Agric. Univ. Pap. 89(1): 71. 1989. Scirpus squarrosus L., Mant. Pl. 2: 181. 1771; C.B. Clarke in Hook. f., Fl. Brit. India 6: 663. 1894. Rikliella squarrosa (L.) J. Raynal, Adansonia 2, 13: 154. 1973; Karthik. \& al., Fl. Ind. Enum. Monocot.: 68. 1989.

Plate 1.c, c1

Annuals with fibrous roots, $6-20 \mathrm{~cm}$ high. Culms tufted, capillary to slender, obtuse-angular or flattened, 0.3-0.6 mm thick, smooth. Leaves shorter than culm, up to $1 \mathrm{~mm}$ wide, acute at apex; ligule absent; lowermost leaves reduced to bladeless sheaths up to $2.5 \mathrm{~cm}$ long, ferrugineous. Inflorescence a pseudo-lateral head of (1-)2-4 spikelets. Involucral bracts $1-3$, leaf-like, dilated at base; lowest erect, looks like continuation of the culm, up to 6 $\mathrm{cm}$ long. Spikelets sessile, strongly squarrose, terete, ovoid to subcylindrical, $2-5 \times 2-3 \mathrm{~mm}$, obtuse at apex, densely many-flowered. Glumes membranous, obovate-rhomboid, c. $1.5 \times 0.3-0.5 \mathrm{~mm}$ (including the $c .0 .7 \mathrm{~mm}$ long, recurved mucro). Stamen 1; filament elongate up to 0.6 $\mathrm{mm}$ long; anther oblong. Ovary oblong; style very short, inconspicuous; stigmas 3 , short, recurved. Achene trigonous, oblong or oblong-obovate, c. $0.5 \times 0.2 \mathrm{~mm}$, smooth; epidermal cells hexagonal.

Flowering and Fruiting: July - October. 


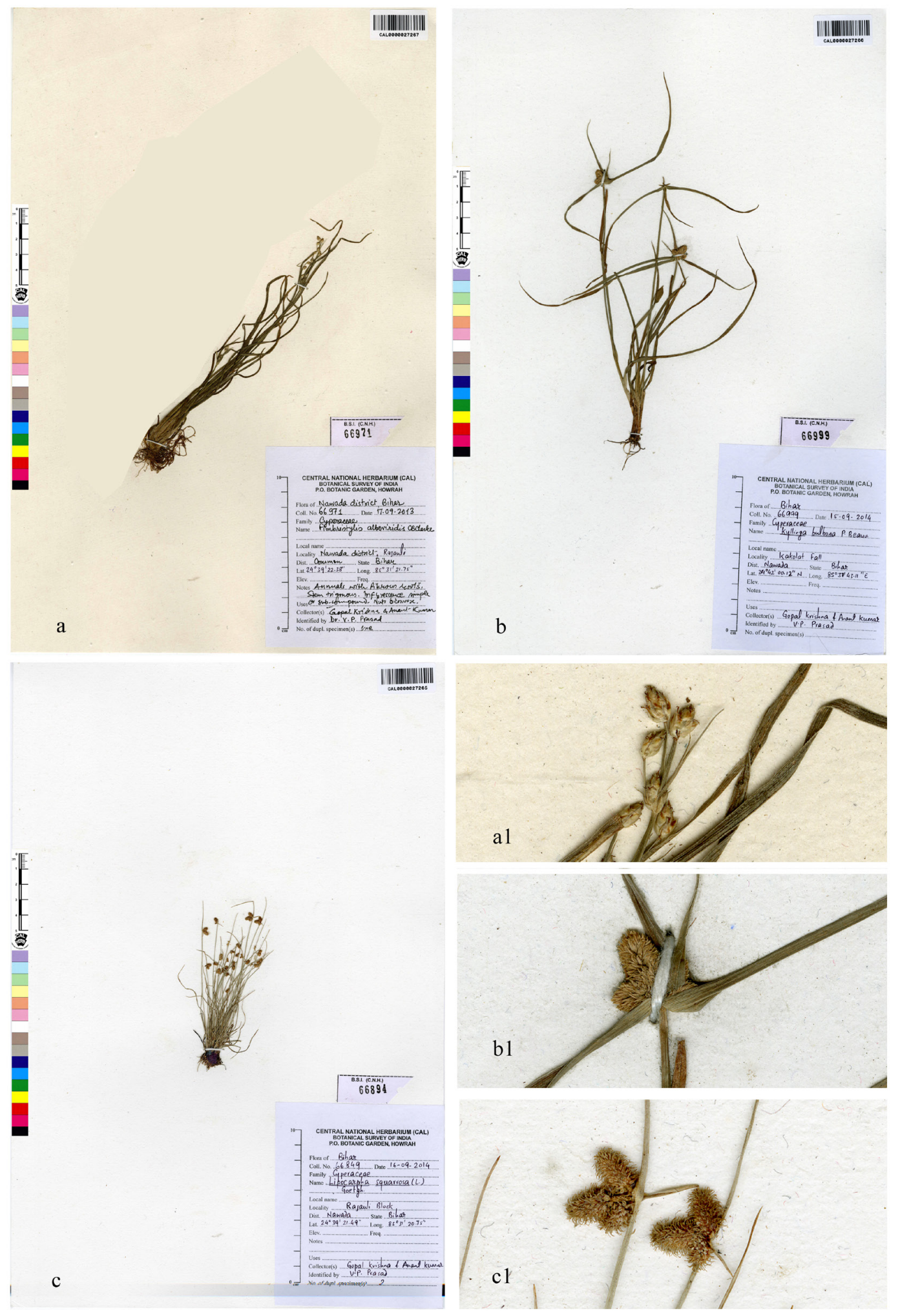

Plate 1. Fimbristylis alboviridis C. B. Clarke: a. Habit; a1. Inflorescence; Kyllinga bulbosa P. Beauv.: b. Habit; b1. Inflorescence; Lipocarpha sqarrosa (L.) Goetgh.: c. Habit; c1. Inflorescence. 
Illustration: C.B. Clarke, Illus. Cyperaceae t. 52, f. 11-13. 1909.

Distribution: Found gregarious patches in moist sandy and hoarse soil in hilly areas during monsoon season; throughout India.

Specimen examined: Bihar: Nawada district, Rajauli Block, 16.09.2014, Gopal Krishna \& Anant Kumar 66894 (CAL).

\section{ACKNOWLEDGEMENTS}

Authors are grateful to Dr. Paramjit Singh, Director, Botanical Survey of India (BSI), and Dr. P.V. Prasanna, Scientist-in-Charge, Central National Herbarium $(\mathrm{CNH})$, BSI, Howrah, for the facilities and encouragement. We thank the Principal Chief Conservator of Forests, Bihar, and all the state forest department officials of Aurangabad and Nawada districts, for their co-operation during the field work.

\section{REFERENCES}

CLARKE, C. B. 1893-1894. Cyperaceae. In: Hooker, J.D. (ed.) The Flora of British India. Vol. 6. L. Reeve, London. pp. 586-748.

CLARKE, C. B. 1909. Illustrations of Cyperaceae. Williams \& Norgate, London,

HAINES, H. H. 1924. Cyperaceae. In: The Botany of Bihar and Orissa. Adlard, London. pp. 888-937.

MOONEY, H. F. 1950. Supplement to the Botany of Bihar and Orissa. Catholic Press, Ranchi.

SHARMA, T. K. and A. K. SARKAR, 2002. Cyperaceae. In: N.P. Singh \& P.S.N. Rao (eds.). Flora of Palamau District, Jharkhand. Botanical Survey of India, Kolkata.

SINGH, N. P., V. MUDGAL, K. K. KHANNA, S. C. SRIVASTAVA, A. K. SAHOO, S. BANDYOPADHYAY, N. AZIZ, M. DAS, R. P. BHATTACHARYA and P.K. HAJRA. 2001. Flora of Bihar Analysis. Botanical Survey of India, Kolkata. pp. 559-587. 